\title{
Exfoliated 'myeloma cells' in the urine of a case of multiple myelomatosis
}

\author{
C. M. PROWSE AND T. E. BLECHER \\ From the Departments of Medicine and Pathology, University of the \\ Witwatersrand, Johannesburg, South Africa
}

SYNOPSIS The clinical features and special investigations in a case of multiple myelomatosis are described. The finding of exfoliated 'myeloma cells' in the urine of this case is thought to be unique these cells closely resembling the myeloma cells seen in the bone marrow. The necropsy findings. indicated that the origin of the cells was from a plasma cell infiltrate of the kidneys rather thaw from isolated plasmacytoma of any part of the urinary tract.

CASE REPORT AND INVESTIGATIONS

The patient was a 46-year-old white man who was admitted to the Johannesburg General Hospital on 9 August 1960. For two months before admission he had been bedridden, incapacitated by backache following an injury.

Examination showed an emaciated, anaemic man who was obviously in great pain. He was normotensive. The skull and spine were tender to percussion and the normal lumbar lordosis had been lost. Marked wasting of general bodily musculature was noted and movement of the limbs was limited due to pain. Fractures of four costochondral junctions were noted on the left.

Routine investigation showed the presence of a hypochromic anaemia of $7 \cdot 4 \mathrm{~g} . \%$ haemoglobin with a normal total and differential leucocyte count, $0.6 \%$ reticulocytes, and an erythrocyte sedimentation rate (Wintrobe) of $69 \mathrm{~mm}$. Blood urea was $116 \mathrm{mg}$. \%, serum calcium $6.8 \mathrm{mEq}$./1., and serum inorganic phosphorus $6.0 \mathrm{mEq} . / 1$. The serum alkaline and acid phosphatases were 7.0 and $5.0 \mathrm{King}$-Armstrong units respectively. The total serum proteins were $11.6 \mathrm{~g} . \%$ and paper electrophoresis showed a $\gamma_{1}$ band, having a mobility slightly faster than that of normal $\gamma$ globulin, which accounted for $46 \%$ of the total proteins. Electrophoretic patterns of serum and urine are shown in Fig. 1. The cerebrospinal fluid showed an increase of protein to $74 \mathrm{mg} . \%$ but was otherwise normal. $X$-ray examination of the skeleton displayed the typical generalized punched-out osteolytic lesions of multiple myelomatosis.

Analysis of urine showed the presence of both albumin and Bence-Jones protein and isosthenuria. Examination at the bedside of a freshly passed spun deposit showed, under the high-power lens, cells suspiciously like myeloma cells. Further spun deposits from freshly passed specimens of urine were then decanted onto glass slides, spread

Received for publication 12 September 1961.

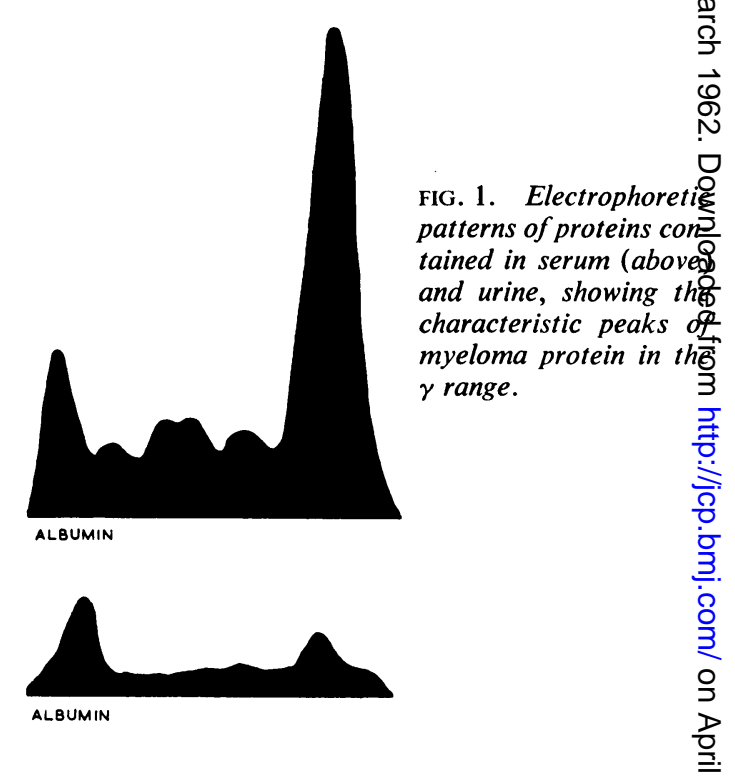

slightly, and air-dried. They were stained with Leishman' stain by the routine technique used for staining blood smears (Whitby and Britton, 1957). Preparations of this type from urine passed on 10 August showed, in additiob to various normal epithelial cells and polymorphonucleag leucocytes, numerous other cells resembling plasma cellso These cells had finely mottled basophilic cytoplasm, oftef abundant, and large round or oval nuclei, of ten eccentriơs ally situated. The chromatin was coarsely clumped or granulated. Occasional binucleate and giant mononu cleated forms of these cells were seen (Figs. 2 and 6 to 9 ).

Taking into consideration the greater degree of spread ing of cells and the poorer preservation of cellular detaid in the urinary smears compared with the bone marrow 


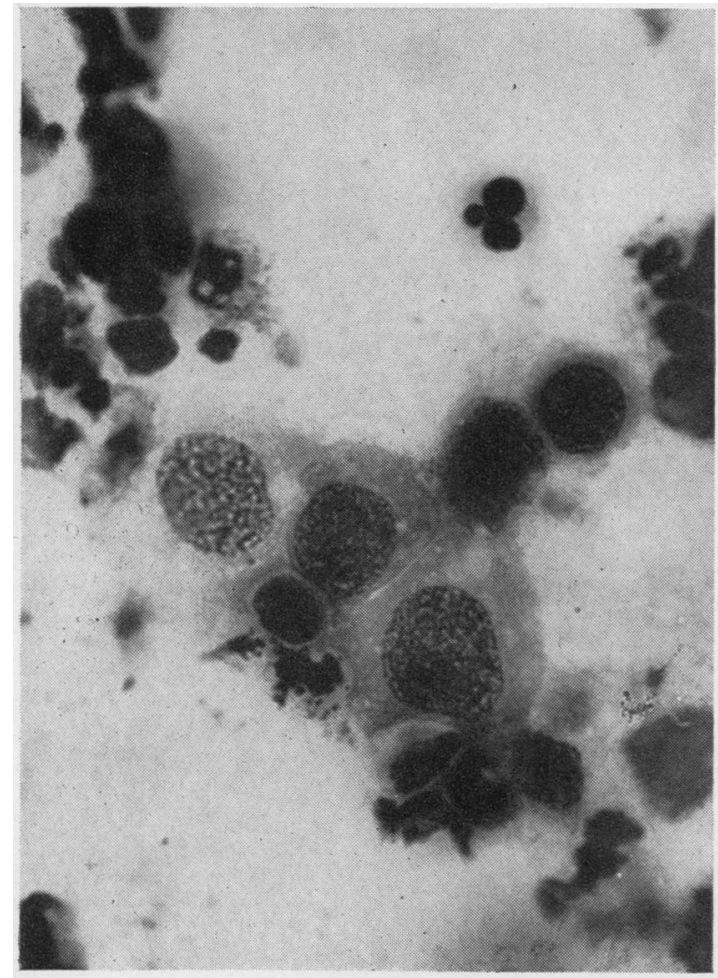

FIG. 2

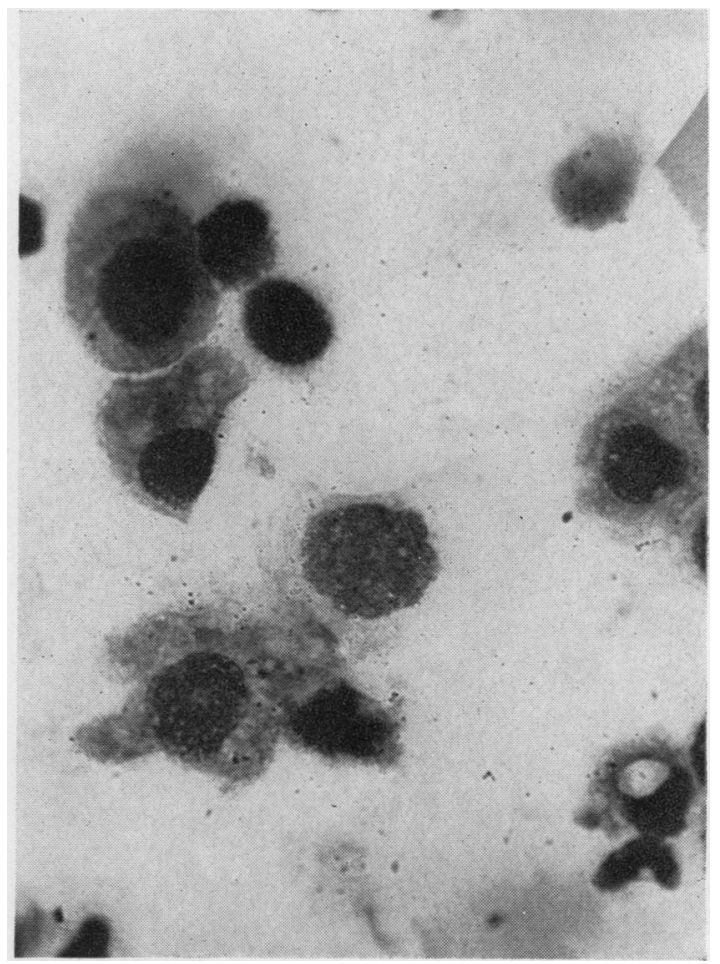

FIG. 3

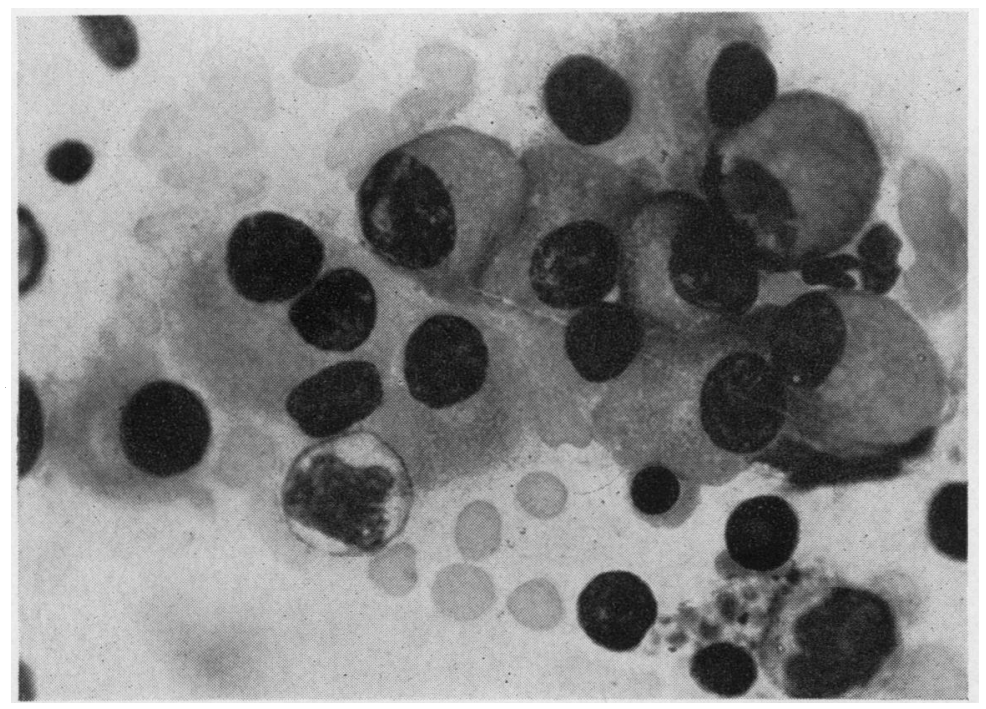

FIG. 2. Urinary sediment showing, centre and above centre, a group of cells described in the text. Leishman's stain $\times 1,000$.

FIG. 3. Urinary sediment. Leishman's stain $\times 1,000$.

FIG. 4. Bone marrow smear. Leishman's stain $\times 1,000$. 


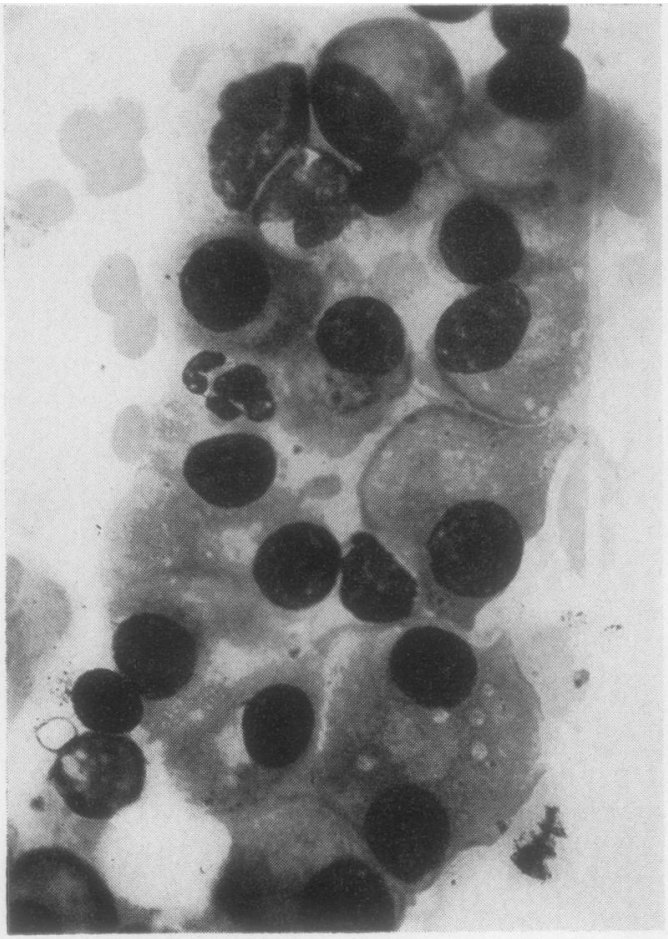

FIG. 5

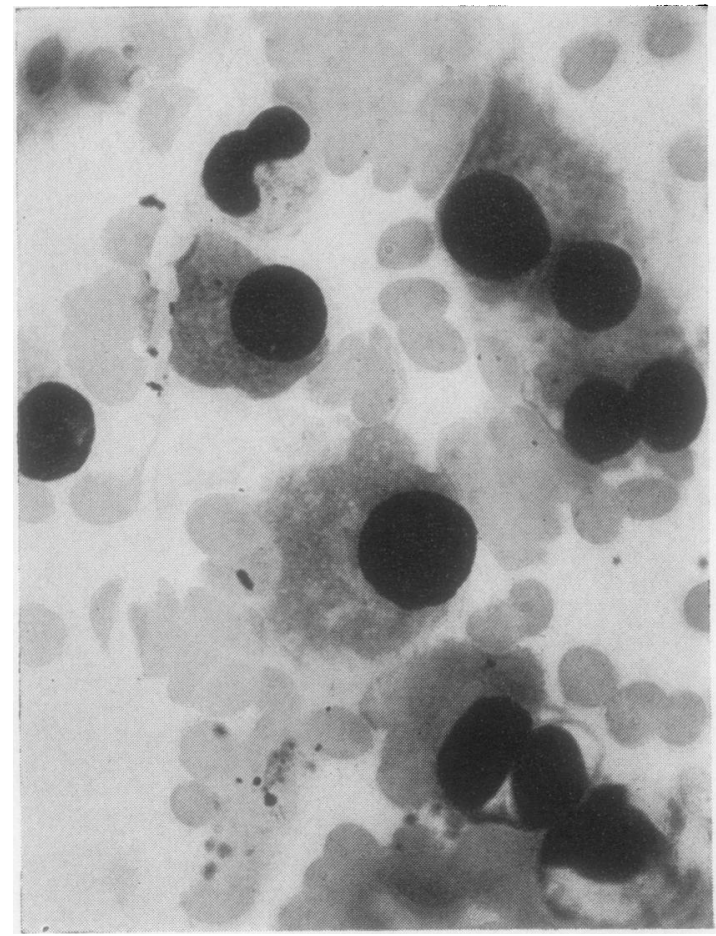

FIG. 5a

FIG. 5. Bone marrow smear showing some 'stretching out' of the myeloma cells. Leishman's stain $\times 1,000$.

FIG. 6. Urinary sediment. Leishman's stain $\times 500$.

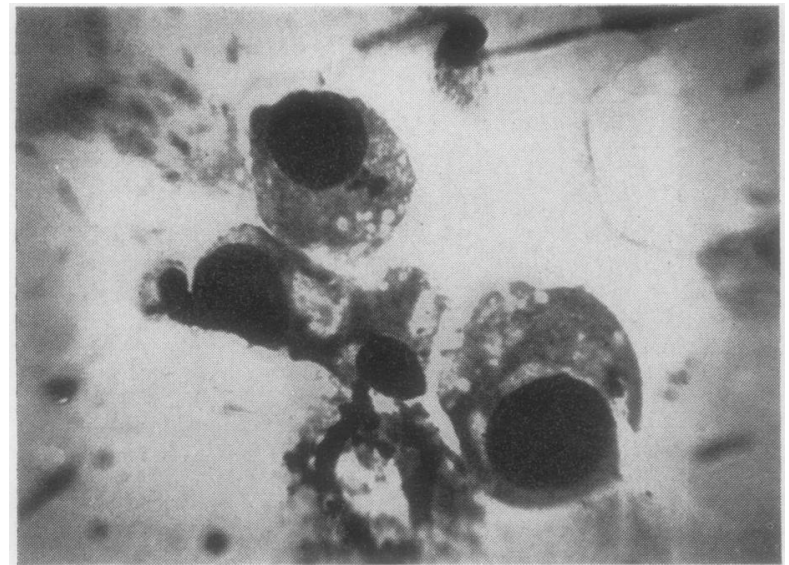

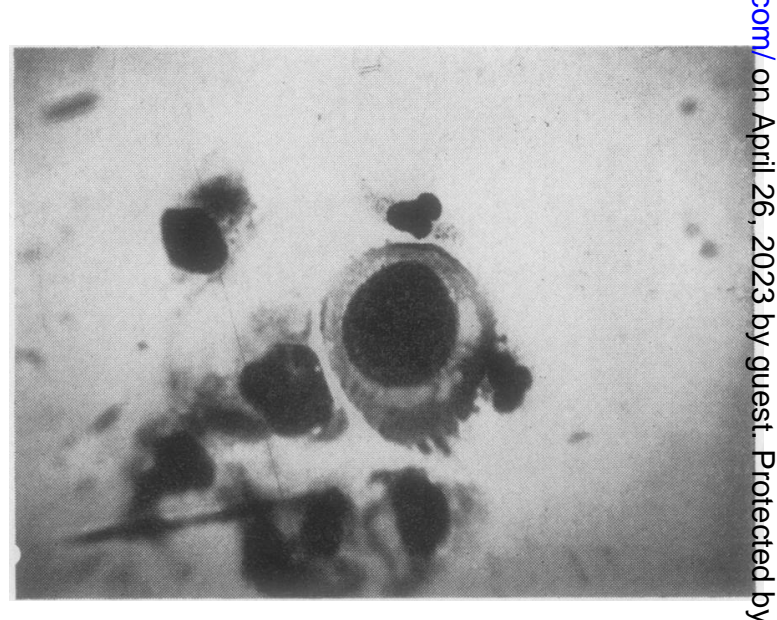

FIG. 7. Urinary sediment. Leishman's stain $\times 500$. 


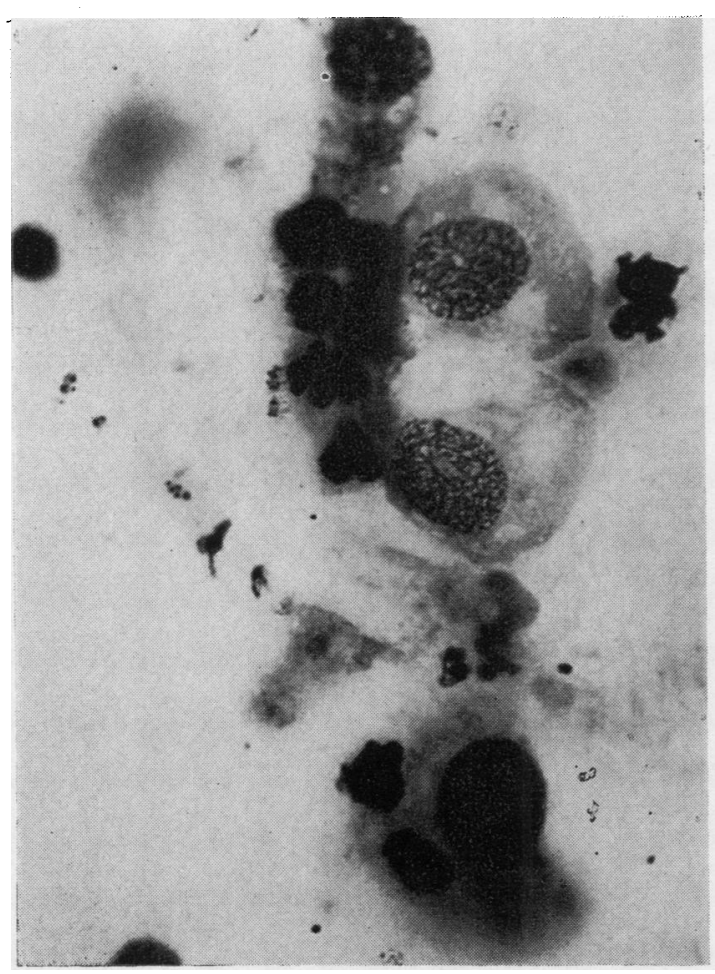

FIG. 8. Urinary sediment. Leishman's stain $\times 1,000$.

smears, it appeared that the abnormal cells in the urine were of the same type as the abundant cells of the plasma cell series, typical of myelomatosis, that infiltrated the patient's bone marrow (Fig. 4). The resemblance was most strikingly appreciated by examining the 'tails' and edges of the bone marrow smears where the cells tended to be spread out to a degree similar to that found in the urinary deposits (Figs. 5 and 5 a).

Subsequent urinary deposits showed reduced numbers and soon after almost none of the 'myeloma cells' described, at which stage preparations stained by the UnnaPappenheim and P.A.S. methods did not materially assist in the characterization of the cells. We thus concluded from their Leishman-stained appearances (with the concurrence of Professor B. J. P. Becker in a personal communication) that these cells were in all probability exfoliated myeloma cells, and refer to them henceforth as such, although conceding that they could conceivably be of some other origin.

Repeated examinations by the same technique of spun deposits from urine passed by several healthy adults revealed no cells at all resembling the abnormal cells in the patient's urine.

Culture of the urine yielded an abundant growth of Esch. coli, Achromobacter, and haemolytic streptococci.

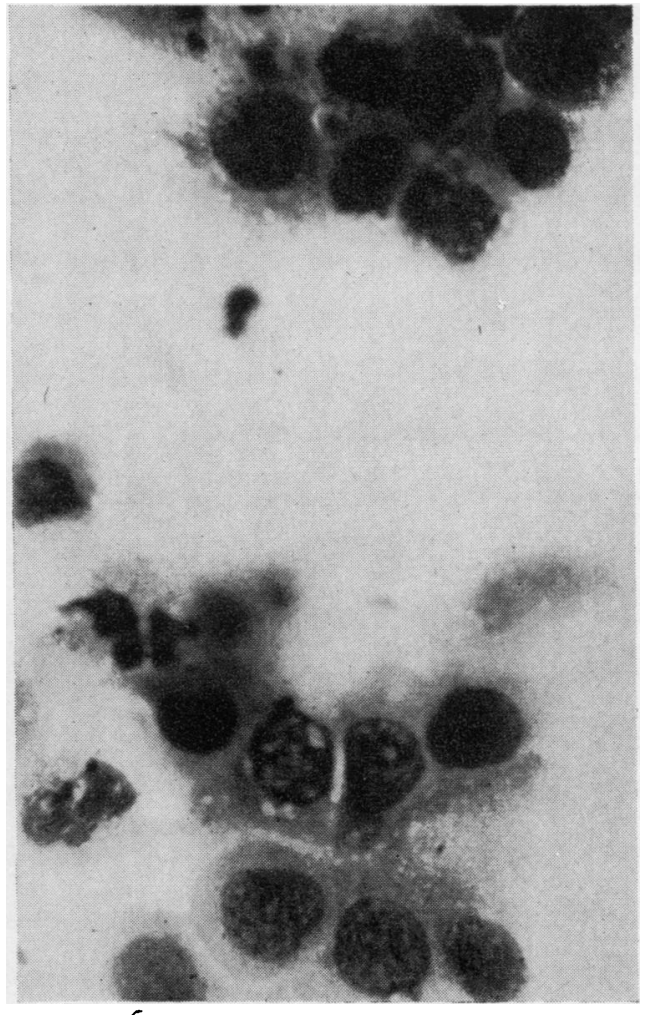

FIG. 9. Urinary sediment. Leishman's stain $\times 1,000$.

The patient's clinical course was relentlessly downhill. About a week before death he sustained a pathological fracture of the right femur and two days before death he had a massive haematuria and thereafter became oliguric. He died on 10 September 1960.

\section{NECROPSY FINDINGS}

Necropsy was performed on 12 September. The findings were those of a severe generalized multiple myelomatosis with osteoporosis and pathological fractures. Paramyloid casts and focal periglomerular fibrosis were present in the kidneys, and the interstitial tissue show diffuse infiltration by non-granular cells, including plasma cells. The right kidney showed, in addition, haemorrhagic infarction and renal vein thrombosis. No isolated plasmacytoma of the urinary tract was found. There was a terminal bronchopneumonia.

\section{DISCUSSION}

It has been stated that some 60 to $90 \%$ of cases of multiple myelomatosis have some renal involvement (Bayrd and Heck, 1947; Sanchez and Domz, 1960) and infection of the urine seems to be the 
commonest complication (Glenchur, Zinneman, and Hall, 1959). In their recent review Sanchez and Domz list the renal syndromes found in myelomatosis (Sanchez and Domz, 1960) but no mention is made of localized renal plasmacytoma. Newns and Edwards (1944), however, described such a case and mentioned the finding of plasma cell types within the renal tubules after death but did not mention whether any of these cells had appeared in the urine. The finding of 'myeloma cells' in urine is not mentioned in a review from the Papanicolaou Cytology Laboratory, New York, of the exfoliative cytology findings in urinary sediments in their large series (Foot, Papanicolaou, Holmquist, and Seybolt, 1958) nor in any other published reports to our knowledge.

In our case, as no plasmacytoma was demonstrated at necropsy in the urinary tract, and as a precipitation of proteins within the tubules may lead to a foreign body reaction with cellular infiltration around the tubules (Anderson, 1953), it seems fair to assume that the 'myeloma cells' appearing in the urine originated by exudation through the tubules of the plasma cells seen in histological sections of the kidneys.

We would like to express our thanks to Dr. K. F. Mills: Superintendent of the Johannesburg General Hospitalo for permission to publish the case records, to Professof? G. A. Elliott, Professor B. J. P. Becker of the Universit of the Witwatersrand, and to Dr. S. Klempman, Depart ment of Exfoliative Cytology at the South African' Institute for Medical Research, for their advice and encouragement.

\section{REFERENCES} Anderson, W. A. D. (1953). Pathology, 2nd ed., p. 589. Mosby, St
Louis.

Bayrd, E. D., and Heck, F. J. (1947). J. Amer. med. Ass., 133, 147. ! Becker, B. J. P. (1960). Personal communication.

Foot, N. C., Papanicolaou, G. N., Holmquist, N. D., and Seybolt J. F. (1958). Cancer, 11, 127

Glenchur, H., Zinneman, H. H., and Hall, W. H. (1959). A.M.A? Arch. intern. Med., 103, 173.

Newns, G. R., and Edwards, J. L. (1944). J. Path. Bact., 56, 259. Sanchez, L. M., and Domz, C. A. (1960). Ann. intern. Med., 52, 44, Whitby, L. E. H., and Britton, C. J. C. (1957). Disorders of the Blood $\overline{\widehat{D}}$ 8th ed., p. 716. Churchill, London.

\section{The January 1962 Issue}

\section{THE JANUARY 1962 ISSUE CONTAINS THE FOLLOWING PAPERS}

Sarcoma of breast, with particular reference to its origin from fibroadenoma R. C. CURRAN and o. G. DODGE Pulmonary cytomegalic inclusion-body disease in a diabetic BRIAN E. HEARD, A. M. HASSAN, and STEPHANIE M. WILSON

Pulmonary nodular granulomatosis caused by inhaled vegetable particles $L$. CROME and J. C. VALENTINE

Histological changes in the thyroid in cirrhosis of the liver A. NICOL and G. SCLARE

Bilateral renal cortical necrosis associated with calcification: report of a case and a review of aetiology M. J. PHILlIPS

Lymphocyte glycogen content in various diseases $\mathbf{R}$. VAUGHAN JONES, G. P. GOFFI, and M. S. R. HUTT

Precipitin reaction between serum and lysed erythrocytes J. F. WILSON and GILLIAN WARREN

Control of blood haemoglobin determinations by a simple effective method IRWIN SCHOEN and MORRIS SOLOMON

The application of the capillary-papain technique to the rapid matching of blood for transfusion B. E. GILBEY and JOAN M. LINDARS

An experiment in the prevention of meningococcal meningitis in Nigeria R. L. vollum and P. w. W. GRIFFITHS

A haemagglutination test for staphylococcal antileucocidin N. P. MARKHAM
Lactate dehydrogenase activity in the diagnosis of malignant effusions J. E. HORROCKS, J. KING, A. P. Bळ WAIND, and J. WARD

The diagnostic value of faecal trypsin estimation in chronic pancreatic disease G. K. MCGOWAN and M. R WILLS

Serum sialic acid levels in health and disease ANN CARTER and N. H. MARTIN

Isolation of a protective gamma-globulin fraction intero fering with the zinc sulphate turbidity test B. NAGANNA B. RAMA RAO, K. R. VENKAIAH, and P. LAKSHMANA RA. A method for the determination of free ${ }^{131}$ in radio 3 iodinated lipids A. G. CoX and ZENA HINCHLIFFE A colorimetric method for the determination of carbo xyhaemoglobin over a wide range of concentrations P. TRINDER and F. E. HARPER

Technical methods

The use of papain-EDTA for Rh typing with 'incomplete' antisera B. P. L. MOORE

An improved plasma recalcified clotting test and it ș $^{5}$ modification as a simple rapid heparin retarded clotting test R. D. EASTHAM

A modified toxigenicity test for Corynebacterium diph theriae S. HAYDEN-SMITH and L. SCHRIRE

The Association of Clinical Pathologists: 67th general meeting

Book reviews

Copies are still available and may be obtained from the PUBLISHING MANAGER, BRITISH MEDICAL ASSOCIATION, TAVISTOCK SQUARE, W.c.1, price 17s. 6D. 